\title{
The contribution of faculty of physical activity and recreation in the development of sport tourism in Albania
}

\author{
ROLAND PALUSHI ${ }^{1} \triangle$ ROBERT ÇITOZI $^{2}$, ELTON SPAHIU ${ }^{2}$ \\ ${ }^{1}$ Eco Tour Albania, Faculty of Physical Activity and Recreation \\ 2 Faculty of Physical Activity and Recreation, Sports University of Tirana
}

\begin{abstract}
Palushi, R., Çitozi, R., \& Spahiu, E. (2015). The contribution of faculty of physical activity and recreation in the development of sport tourism in Albania. J. Hum. Sport Exerc., 9(Proc1), pp.S515-S520. Albania is a country poorly known in Europe despite its rich history and cultural heritage. Otherwise known as "the land of eagles" or "the bridge linking the east with the west", Albania has given a lot to the history and culture of Europe. In 1992 this country came out of a long communist dictatorship and began its path to democratization. Tourism, which during the communist era was considered as "a problem of society", is taking a leap today, becoming one of the main branches of the Albanian economy. In this context there was needed to inform and educate the public for the advantages and the disadvantages of tourism. The GeoPhysics condition of Albania provides enough opportunities for the development of different forms of Sports Tourism. With about $70 \%$ of the mountain surface, Albania offers the possibility of outdoor sports development as: Hiking, Mountaineering, Sking, etc. The $400 \mathrm{~km}$ coastline offers the possibility of the development of aquatic sports such as Kayak at Sea, Diving, Kite Surf, etc. Numerous rivers and lakes offer the opportunity of developing sports: Fishing, Rafting etc. This rich natural tourist potential and the growing demand of tourists that practice these kinds of sports faces with tourist and cultural deficiencies service that Albania offers. For this reason the Sports University of Tirana and in particular the Faculty of Physical Activity and Recreation have created opportunities to students in this field. Between lessons in the auditorium and hours of practice in mountainous areas and in coastal areas, those first generation students in sports and recreation tourism was given the opportunity to be pioneers in the development and spread of this sports tourism culture in Albania. Key words: SPORT TOURISM, TOURISTIC POTENTIAL, CULTURAL HERITAGE.
\end{abstract}

\footnotetext{
Corresponding author. Eco Tour Albania, Faculty of Physical Activity and Recreation, Bulevardi Zogu I,Tiranë, Albania E-mail: rolandpalushi@yahoo.com 9th INSHS International Christmas Sport Scientific Conference, 4-6 December 2014. International Network of Sport and Health Science. Szombathely, Hungary. 


\section{INTRODUCTION}

Albania is a country poorly known in Europe despite its rich history and cultural heritage. Otherwise known as "The Land of Eagles" or "The bridge linking the east with the west", Albania has given a lot to the history and culture of Europe.

In 1991 this country came out of a long communist dictatorship and began its path to democratization. Tourism, which during the communist era was considered as "a problem of society", is taking a leap today, becoming one of the main branches of the Albanian economy. In this context there was needed to inform and educate the public for the advantages and the disadvantages of tourism.

The Geo-Physics condition of Albania provides enough opportunities for the development of different forms of Sports Tourism. With about $70 \%$ of the mountain surface, Albania offers the possibility of outdoor sports development as: Hiking, Mountaineering, Skiing, Rafting, Adventure Racing etc. The $427 \mathrm{~km}$ coastline offers the possibility of the development of aquatic sports such as Kayak at Sea, Diving, Kite Surf, etc. Numerous rivers and lakes offer the opportunity of developing sports: Fishing, Rafting, White Water Kayak etc.

This rich natural tourist potential and the growing demand of tourists that practice these kinds of sports faces with tourist and cultural deficiencies service that Albania offers. For this reason the Sports University of Tirana and in particular the Faculty of Physical Activity and Recreation science 5 years have created opportunities to students in this field. Between lessons in the auditorium and hours of practice in mountainous areas and in coastal areas, those first generation students in sports and recreation tourism was given the opportunity to be pioneers in the development and spread of this sports tourism culture in Albania.

\section{MATERIAL}

Tourism and sport are key elements of today's culture and have a specific influence on the behavior of society. As the founder of the modern Olympic Games, Pierre de Coubertin ones stated 'competition produces harmony between competitors and the organizations or nations they represent'. It was his belief that sport brings people and nations together.

Especially since the 1960's sport has become a huge international matter with large amount of media attention, money and also political interest. On the other hand tourism remains the world's largest industry as well as very developing and growing. For this reason a combination between the two can be very lucrative and has a lot of cultural influence.

If we talk about Sport as a way of tourism, we must define what is been considered as Sport Tourism. Therefore conceptualizing sport tourism is a good starting point in this study.

Broadly defined, Sport Tourism includes travel away from one's primary residence to participate in a sport activity for recreation or competition, travel to observe sport at the grassroots or elite level, and travel to visit a sport attraction such as a sport hall of fame or a water park (Gibson et al. 1997). 
The concept of sport-related tourism has become more prominent over the last few years; however, there have been difficulties defining the sector and academia have frequently seen sport and tourism as separate spheres of activity.

Throughout history, travelling for sport is evident, whether it involved journeying to the next village to play a game of football or in recent times (as mountains became an attraction instead of an object of fear) to go skiing.

Sports tourism itself comes in three versions: "leisure sports tourism" or "active sport tourism" referring to people who travel to take part in sporting activities, "sport event tourism" which refers to people who travel to watch a sporting event and "nostalgia sport tourism" which includes visits to sports museums or stadiums.

One of the fastest growing sectors of the global travel and tourism industry. Value in 2003 as high as $\$ 51$ billion, equivalent to $10 \%$ of the global tourism market. 1.03 trillion US-\$ ( $€-740$ billion) in 2011, corresponding to an increase in real terms of $3.8 \%$ from 2010. By 2014, travel and tourism is expected to be more than $11.5 \%$ of global GDP.

The economies of cities, regions and even countries around the world are increasingly reliant on the visiting golfer and skier or the traveling football, rugby or cricket supporter. (Source Nov. 2013 Sport Business report sportbusiness.com).

Sports-related travel is a $\$ 182$ billion industry, generating over 47 million hotel room nights annually.

$>$ Sports related corporate incentive travel.

$>$ Team and sports event participation travel.

$>$ Family and sports spectator travel.

$>$ Adventure and sports fantasy travel. (www.sportstravelmagazine.com)

Sport is regarded as the world's largest social phenomenon. Tourism is the world's biggest industry. Is Sport Tourism greater than the sum of its parts?

As we know Sport Tourism is... 3 Dimensional concept involving sport and tourism. (Delpy, L.1998)

$>$ Travel to play sport

$>$ Travel to watch sport

$>$ Travel to sport attractions

.....but what about....Vacations where sport is secondary motivation...!

According to World Tourism Organization (WTO), two significant travel trends will dominate the tourism market in the decade 2010-2020:

Mass marketing is giving way to one-to-one marketing with travel being tailored to the interests of the individual consumer.

$>$ A growing number of visitors are becoming special interest travellers who rank SPORT as one of the top 10 reasons for travelling.

\section{RESULTS}


-The Strategy for Tourism Development in Albania.

$>$ When the Strategy for Tourism Development in Albania was approved in 2003, Albania represented a emerging market which had considerable potential to be used for tourism development, by presenting the image of a tourist destination such as described by the slogan: "Albania, yours to discover".

$>$ The strategy was designed to expand and strengthen this sector, focusing particularly on the sustainable development principle and on the identification of challenges to optimize contributions to this sector.

$>$ Though eleven years have passed, there are still important aspects of the strategy and its plans of action which have not been achieved.

Emerging markets refers to developing countries experiencing rapid growth and industrialization, with some characteristics of a developed market". (Wikipedia)

-During this period of time, the number of tourists has continuously increased by maintaining a constant number of ethnic tourists. The number of foreign visitors has increased from 309.000 in 2003, to approximately 1,100.000 million in 2011.

The income from tourism as part of the GDP is calculated to be from $3.8-4 \%$ or approximately 45 billion Lek (Albanian money).

$>$ The contribution of tourism to the Albanian economy is at around $11 \%$.

$>$ The number of those employed in the tourism industry is at around 138,000 .

$>$ Albania occupies around $0.6 \%$ of the total demand for tourism in the tourism market of the Central and Eastern Europe.

$>$ Export of visitors occupies around $50 \%$ of the Albanian exports.

-Exploring Mountain Tourism in Albania.

$>$ Due to the prevalence of exceptional hilly and mountainous landscape in Albania - (almost $2 / 3$ of the country's surface area) - there are remarkable potentials for the development of a wide range of mountain tourism activities, which can take place during the cold winter season (white tourism) and during the warm season (green tourism).

$>$ The main tourist activities that can be carried out in mountainous territories are winter sports, tracking, climbing, excursions, eco-tourism, fishing in rivers and kayak, mountain biking, etc.

$>$ Requires investments not only in skiing infrastructure but also in the construction of accommodation structures.

Mountains are ideally places for doing such activities and tourism development on mountains is often based on sport and recreation. It brings numerous benefits to mountain areas, but there are a several negative environmental impacts that must be reduced.

This primarily refers to soil erosion and compaction, trail widening, changes in vegetation cover, air- and water pollution etc.

A sustainable development plan to protect the natural environment is crucial and must be made for each tourist destination. 
Visitor education can also bring positive results in terms of sustainable development. Visitors must follow the rules, which are aimed at reducing environmental damage.

A great role in the education of population and visitors to protect the natural environment are playing our students of Faculty of Physical Activity and Recreation.

\section{DISCUSSION}

The aims and objectives of our Faculty programs are to introduce students to the key definitions of Sport, Health, Adventure and Sport Tourism, to familiarize students with the main features of Sport, Health, Adventure and Sport Tourism, to identify the various sectors associated with Sport, Health, Adventure and Sport Tourism, and explain their organizational structures and objectives, to highlight the multi-disciplined nature of Sport, Health, Adventure and Sport Tourism, to generate student expertise in problem solving skills which are sensitive to the future needs and demands of Sport, Health, Adventure and Sport Tourism and to develop awareness of the potential of Sport, Health, Adventure and Sport Tourism in terms of management, planning and development.

Albania participated in the London Tourism Fair, World Travel Market, organized in London, 3-6 November 2014. Our country was represented by a delegation headed by the Minister of Urban Development and Tourism. In her interview for "Euro-sport", the Minister underlined the tourism potentials of our country, such as the endless water resources, the mountains, and the seacoast as an outstanding opportunity for sporting activities such as rafting, alpinism, parachuting, water sports activities, etc. "Adventure tourism and sports tourism in general are now part of the Albanian government vision and strategy. We are working intensively to improve the sports tourism infrastructure".

"With the purpose of making Albania a competitive destination in the international tourism market and creating favorable conditions for an economic growth in the sector, we have designed the Strategy of Tourism Development 2014-2020 in collaboration with Harvard University".

This is the reason why the collaboration with the National Agency of Tourism for us as Faculty of Physical Activity and Recreation is very important for the future of Sport and Adventure tourism in Albania.

\section{CONCLUSIONS}

Albania, even though a small country in the hearts of the Balkans, offers an active holiday for visitors, a combination of sea and sand tourism with cultural tourism and recreational sports activities. The hospitality, the rich cuisine are other reasons to get to know and visit Albania.

As long as sport tourism is one of the best opportunities to the Albania economic development we have to be focused in:

Remarkable increase in opportunities in sport tourism

$>$ People focused profession.

$>$ Specific knowledge and skills needed.

D Education and training programs are relatively rare.

$>$ Sector needs professionalism - linked to quality of experience. 
$>$ Recognition needed from academia / industry.

$>$ Need to develop links between academic institutions like our Faculty and industry to meet present and future targets for trained professionals in sport and tourism.

Sports University of Tirana role in preparation of Sport Touristic Guide for the future of this strategic sector is very important.

\section{REFERENCES}

1. Bitzenis, \& Nito. (2005). Obstacles to entrepreneurship in a transition business environment - the case of Albania. Journal of small business and enterprise development, 12(4) pp. 564-578.

2. Euromonitor. (2012). Travel and Tourism in Albania. Euromonitor.

3. Gibson, B. K., Loewenstein, M., Mushotzky, R. F., 1997, MNRAS 290, 623.

4. Gorica, K. (2006). ISSUES OF EUROPEAN INTEGRATION FOR TOURISM. Tirana: University of Tirana.

5. Kruja, D. (2011). The Special Interest Tourism. TURIZAM, pp. 77-89.

6. Pirozzi, G. (2008). Country profile: Education in Albania. Retrieved May 30, 2012, from unicef.org: http://www.unicef.org/ceecis/Albania.pdf

7. SNV. (2009). The market for responsible tourism products. SNV.

8. UNDP Albania. (2005). Strategy and Action Plan for the Development of the Albanian Tourism Sector Based on Cultural and Environmental Tourism. Tirana: UNDP Albania.

9. UNESCO. (2004). Establishment of an office for rural tourism in southwestern Montenegro. Belgrade: UNESCO.

10. University of Western Sydney. (2001). Exploring the phenomenon of rural tourism and tourism's interaction with host rural communities. Sidney: School of Environment and agriculture. 